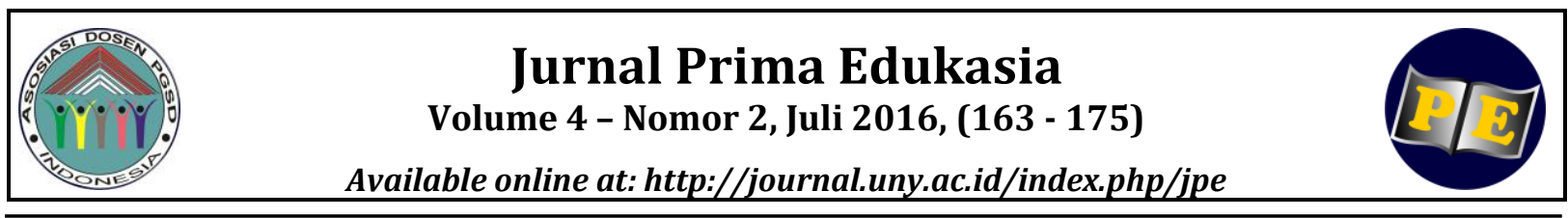

\title{
KEEFEKTIFAN PEMBELAJARAN METEMATIKA MELALUI PENGGUNAAN MEDIA BENDA KONKRET PADA KELAS V SD TIMURAN
}

\author{
Novi Kristiani ${ }^{1)}$, Zuhdan Kun Prasetyo ${ }^{2}$ ) \\ ${ }^{1}$ SD Negeri Timuran Yogyakarta. Jalan Prawirotaman 1, Brontokusuman, Mergangsan, Yogyakarta \\ 55153, Daerah Istimewa Yogyakarta, Indonesia \\ ${ }^{2}$ Pendidikan Fisika, Universitas Negeri Yogyakarta. Jalan Colombo No.1, Karangmalang, Yogyakarta \\ 55281, Indonesia \\ Email: ${ }^{1}$ novikristiani51@yahoo.co.id, ${ }^{2}$ zuhdan@uny.ac.id
}

\begin{abstract}
Abstrak
Penelitian ini bertujuan untuk meningkatkan keefektifan pembelajaran melalui penggunaan media benda konkret pada siswa kelas V SD Timuran Yogyakarta. Penelitian ini merupakan penelitian tidakan kelas (PTK), yang terdiri atas dua siklus, yang setiap siklus mengikuti tahapan-tahapan Model Kemmis dan Taggart yang meliputi: observasi perencanaan, tindakan, dan refleksi. Subjek penelitian adalah siswa kelas V SD Timuran Yogyakarta yang terdiri atas 11 siswa laki-laki dan 14 siswa perempuan. Teknik pengumpulan data yang digunakan adalah teknik observasi, tes, dan angket. Kriteria keberhasilan penelitian diukur dari (1) nilai rata-rata kelas minimal 75, (2) minimal $75 \%$ siswa telah mencapai KKM yang ditetapkan yaitu 75, dan (3) minimal 75\% siswa memberikan respon terhadap pembelajaran dalam kategori baik. Hasil penelitian menunjukkan bahwa penggunaan media benda konkret dapat meningkatkan keefektifan pembelajaran. Hal itu terbukti dari tercapainya semua kriteria keberhasilan yang ditetapkan dalam penelitian, di antaranya: (1) hasil tes menunjukkan peningkatkan nilai rata-rata kelas (2) persentase siswa yang mencapai nilai KKM yang ditetapkan sekolah meningkat, dan (3) respons siswa terhadap pembelajaran matematika dengan menggunakan media benda konkret dalam kategori baik.
\end{abstract}

Kata Kunci: keefektifan, pembelajaran matematika, media benda konkret.

\section{IMPROVING THE EFFECTIVENESS OF TEACHING MATHEMATICS THROUGH THE CONCRETE MEDIUM TO FITH GRADE STUDENT OF SD TIMURAN}

\begin{abstract}
The aims of this research are to improve the instruction effectiveness through the use of concrete media to the fith grade students of SD Timuran. This research is a classroom action research study consisting of two cycles, each of which follows the stages in Kemmis and Taggart model including: planning, action and observation, and reflection. The subjects of this research were 11 male student and 14 female students of SD Timuran Yogyakarta. The data were collected through observation, test, and questionnaires. The criteria of success were (1) the minimal average class score was 75, (2) a minimum of 75\% students exceeded the minimum achievement criterion, and (3) a minimum of $75 \%$ student gave a good response to the teaching. The results show that the use of the concrete media can improve the instruction effectiveness. It proves that the criteria of this research can be achieved, including: (1) the average of the test results increases, (2) the percentage of the students who exceed the minimum achievement criterion increases, and (3) the students' responses to mathematics teaching using concrete media are in a good category.
\end{abstract}

Keywords: effectivenes, mathematics teaching, concrete media

How to Cite: Kristiani, N., \& Prasetyo, Z. (2016). Keefektifan pembelajaran metematika melalui penggunaan media benda konkret pada kelas V SD Timuran. Jurnal Prima Edukasia, 4(2), 163-175. doi:http://dx.doi.org/10.21831/jpe.v4i2.7791

Permalink/DOI: http://dx.doi.org/10.21831/jpe.v4i2.7791 
Jurnal Prima Edukasia, 4 (2), Juli 2016 - 164

Novi Kristiani, Zuhdan Kun Prasetyo

\section{Pendahuluan}

Pembelajaran matematika berlangsung hanya dengan menyangkut substansi, tanpa mengembangkan kemampuan melakukan yang berhubungan dengan proses-proses mental seperti penalaran dan sikap ilmiah. Salah satu penyebab ini adalah proses pengajaran guru yang masih bersifat pasif dengan menggunakan methode ceramah. Proses pembelajaran matematika diharapkan mempunyai pengalaman langsung untuk mengembangkan kompetensi agar mengenalbenda-benda yang berada di lingkungan sekitar kita. Pemahaman matematika sebainya menumbukan kemampuan berfikir logis dan bersikap ilmiah. Peran guru dalam memfasilitasis siswa untuk mencapai standar kompetensi dan kompetensi dasar yang dilandasi dengan pemberdayaan siswa untuk membangun kemampuan, bekerja ilmiah dan membangun pengetahuan sendiri.

Untuk mencapai tujuan pembelajaran yang efektif peran seorang guru dalam memimpin belajar sebagai fasilitator. Mengajar bukanlah menyampaikan materi saja, melainkan suatu proses membelajarkan siswa sehingga terjadi interaksi belajar mengajar dengan perencanaan dan pengaturan yang sesuai dan seksama. Perencanaan dan menggunaan metode yang benar akan memberikan pengajaran yang efektif. Menurut Hamalik (2009, p.14) pembelajaran adalah suatu kombinasi yang tersusun meliputi unsur-unsur manusiawi, material, fasilitas, perlengkapan dan prosedur yang saling mempengaruhi untuk mencapai tujuan pembelajaran. Guru juga harus dapat menyediakan sumber belajar, merancang kegiatan yang harus dilaksanakan siswa, mengatur pengalokasian waktu, menyediakan tempat belajar, dan mengatur pengelolaan kelas. Hal ini juga sesuai pernyataan Gagne \& Briggs (1979, p.19) yang mengemukakan "instruction is the means employed by teachers, designers of materials, curriculum specialists, and others whose purpose it is to develop an organized plan to promote learning". Pernyataan tersebut mengandung makna bahwa pembelajaran adalah pekerjaan guru, pembuat bahan pelajaran, ahli kurikulum dan yang lainnya, yang bertujuan membangun rencana untuk memajukan proses belajar.

Johnson (2002, p.43) menyatakan bahwa:

"When young people can connect the content of academic subject such as mathematics, science, or history with their own experience, they discover meaning, and meaning gives them a reason for learning". Maksudnya adalah ketika murid dapat mengaitkan isi dari mata pelajaran seperti matematika, ilmu pengetahuan alam, sejarah dengan pengalaman mereka sendiri, maka mereka akan menemukan makna dan makna tersebut akan memberikan mereka alasan untuk mereka belajar. Beberapa penyebabnya adalah pembelajaran disekolah cenderung menekankan pada aspek kognitif, dengan mengadakan hafalan untuk mendapatkan ilmu, bukan mengembangkan ketrampilan berpikir siswa, mengembangkan aktualisasi konsep dengan diimbangi pengalaman konkret (Depdiknas, 2003, p.3)

Berdasarkan pada aktivitas siswa di dalam kelas, yang paling sering ditemukan adalah aktivitas verbal yaitu berbicara. Pada umumnya guru mendominasi aktivitas verbal misalnya berceramah, menjelaskan petunjuk kerja, memimpin diskusi, mengajukan pertanyaan kepada murid. Dalam hal mengajukan pertanyaan, sering kali pertanyaan dari guru tersebut kurang efektif bagi siswa. Dalam pembelajaran matematika bertanya dipandang sebagai kegiatan guru untuk mendorong, membimbing dan menilai kemampuan berpikir siswa, bagi diri sendiri kegiatan bertanya merupakan bagian yang penting dalam melaksanakan pembelajaran untuk menggali informasi, mengkonfirmasi apa yang sudah diketahui, dan mengarahkan perhatian pada aspek yang belum diketahuinya. Pengetahuan siswa hendaknya tidak diperoleh ari hasil hafalan, tetapi hasil menemukan dan menggeneralisasi sendiri.

DePorter \& Hernacki $(2011$, p.8) menyatakan bahwa proses pembelajaran efektif jika pembelajaran menyenangkan. Guru dituntut untuk mampu menumbuhkan rasa senang pada suatu mata pelajaran. Dalam hal ini guru harus menuangkan kreativitasnya dalam menciptakan pembelajaran yang inovatif dengan mengerahkan Sumber Daya Manusia (SDM) dan sumber belajar yang optimal. Guru sebagai fasilitator pada mata pelajaran matematika harus berusaha semaksimal mungkin agar bisa memfasilitasi penyampaian matematika yang sesuai dengan taraf perkembangan siswa sehingga tujuan dari matematika benar-benar bisa terwujud. Inilah tantangan bagi guru agar pembelajaran menjadi menarik dan menyenangkan bagi siswa sehing- 
Jurnal Prima Edukasia, 4 (2), Juli 2016 - 165

Novi Kristiani, Zuhdan Kun Prasetyo

ga materi-materi yang ada dalam ruang lingkup matematika dapat diserap dengan baik.

Ruang lingkup mata pelajaran matematika pada satuan pendidikan SD/MI meliputi aspek-aspek bilangan, geometri, dan pengolahan data. Materi matematika merupakan materi yang abstrak. Pembelajaran matematika pada tingkat sekolah dasar memerlukan penyajian dan media yang mampu menurunkan tingkat keabstrakan materi matematika dan mampu menarik minat siswa untuk belajar. Pembelajaran matematika khususnya meteri geometri merupakan materi yang cukup sulit untuk memberikan contoh yang konkret pada siswa. Materi ini mulai diajarkan dari kelas 4 dimulai dengan penanaman konsep, dilanjutkan di kelas 5 mengidentifikasi sifat-sifat bangun runang dan dilanjutlan di kelas 6, yang diharapkan sudah memahami sifat-sifat bangun ruang. Namun pada kenyataannya sampai di kelas 5 anak-anak belum paham betul dengan materi geometri

Pembelajaran matematika biasanya diajarkan dengan menggambar di papan tulis. Hal tersebut juga didasarkan wawancara dengan teman sejawat guru kelas V SD Timuran. Kenyataan di lapangan pembelajaran model tersebut belum bisa memfasilitasi siswa untuk mengkonkretkan pembelajaran matematika pada materi geometri yang bersifat abstrak dan sehingga kurang mendapatkan respon dari siswa. Hal ini kemungkinan disebabkan karena pemahaman konsep geometri melalui pembelajaran yang diajarkan dengan menggambar di papan tulis masih semi abstrak menurut Muhsetyo (2003, p.12). Sedangkan siswa SD ada pada tahap operasional konkret. Menurut Piaget yang dikutip oleh Santrock (2012, p.329) menyatakan bahwa tahap operasional konkret (concrete operational stage) berlangsung pada usia sekitar 7 hingga 11 tahun. Pada tahap ini, anak-anak dapat melakukan operasi konkret, mereka juga dapat bernalar secara logis sejauh penalaran itu dapat diaplikasikan pada contohcontoh spesifik atau konkret.

Sebagai upaya memenuhi harapan supaya berhasil dalam kegiatan belajar mengajar, maka pihak sekolah perlu memperhatikan dan mempunyai kewajiban untuk menyediakan sarana dan prasarana yang diperlukan untuk menyelenggarakan proses pendidikan. Dalam proses kegitan pembelajaran sarana prasarana pembelajaran di SD timuran sudah tersedia akan tetapi penggunaanya kurang efektif hal tersebut dalam menggunaan media pembelajaran hanya 2 orang guru dari 12 guru, yang hanya menggunakan media pembelajaran. (Sumber wawancara Pengawas Sekolah dengan petugas perpustakaan yang dibuktikan dengan daftar peminjaman alat peraga di perpustakaan sekolah). Untuk meningkatkan prestasi pada mata pelajaran matematika siswa seharusnya dibiasakan untuk memecahkan masalah dan menemukan ide yang berguna untuk dirinya sendiri dan orang lain. Demi mewujudkan hal tersebut guru hendaknya memahami dan melaksanakan prinsip-prinsip pembelajaran yang berkualitas yakni pembelajaran yang berpusat pada siswa bukan pembelajaran yang berpusat pada guru. Pembelajaran perlu dirancang supaya memberikan kesempatan dan kebebasan berkreasi bagi siswa secara berkesinambungan. Guru harus dapat memilih dan menggunakan pendekatan yang sesuai dengan materi yang diajarkan, supaya meteri yang diberikan dapat dipahami jelas konsepnya.

Berdasarkan pengamatan ulang untuk dikonfirmasi yang penulis lakukan pada hari rabu tanggal 27 Maret 2013, hasil pembelajaran Matematika belajar matematika kelas IV di SDN Timuran masih belum memuaskan. Hal ini dapat dilihat dari data hasil ulangan harian matematika, menunjukkan bahwa penguasaan siswa terhadap materi pelajaran masih rendah. Dari 25 siswa yang mengikuti ulangan harian, 10 siswa tuntas dan 15 siswa belum tuntas. Rata-rata kelas 64,30. Dimana sebagian besar siswa berada dibawah standar ketuntasan minimal yang ditetapkan sekolah yaitu. Sumber: daftar nilai kelas 5 SDN Timuran. Saat penulis mengadakan survey pengamatan di kelas $\mathrm{V}$ SDN Timuran bahwa pembelajaran matematika masih didominasi dengan menggunakan metode ceramah dan kegiatan yang berpusat pada guru.

Berdasarkan teori dan kenyataan tersebut peneliti tertarik untuk melakukan penelitian tindakan pada pembelajaran matematika dengan menggunakan media benda konkret karena mempunyai kelebihan yaitu lebih mengaktifkan siswa dan tentunya lebih menarik dan menyenangkan, karena menggunakan benda-benda kongkret untuk menvisualisasi pembelajaran matematika.

Proses pembelajarannya menggunakan media benda konkret yang dilakukan pada penelitian ini, siswa dibagi dalam kelompok kecil, dengan tiap kelompok diberikan seperang- 
Jurnal Prima Edukasia, 4 (2), Juli 2016 - 166

Novi Kristiani, Zuhdan Kun Prasetyo

kat alat untuk mempraktekan media benda konkret tersebut. Heinich, et al., (1996, p.8) menyatakan bahwa a medium (pliral, media) is a channel of communication, refers to anything that carries information between a source and receiver. Berdasarkan uraian tersebut dapat didenisikan bahwa media merupakan semua alat bantu yang digunakan guru dalam proses pembelajaran. Hal senada juga dikatakan Winkel $(2009$, p.319) bahwa media pengajaran adalah suatu sarana non personal (bukan manusia) yang digunakan oleh pengajar yang memegang peranan penting dalam proses belajar mengajar, untuk mencapai tujuan intruksional.

Diharapkan dengan kelompoknya, semua siswa dapat mencoba mempraktekan dengan benda-benda konkret yang telah disediakan oleh guru dan siswa yang dibawa dari rumah. Soal-soal diberikan dalam bentuk Lembar Kerja Siswa (LKS) yang dikerjakan dalam kelompok yang beranggotakan 5 orang tiap kelompoknya. Melihat kelebihan pembelajaran dengan menggunakan media benda konkret, kemungkinan dapat meningkatkan keefektifan pembelajaran metematika siswa kelas V. Kelebihan-kelebihan tersebut menjadi alasan peneliti untuk meningkatkan keefektifan pembelajaran matematika dengan menggunakan media benda konkret

\section{Metode}

Desain Penelitian

Jenis penelitian yang ditetapkan berupa penelitian tindakan kelas yang bersifat kolaboratif. Prosedur dan langkah langkah penelitian mengikuti prinsip prinsip dasar yang berlaku dalam penelitian tindakan kelas. Desain penelitian yang digunakan adalah menggunakan desain penelitian yang dikembangkan oleh Kemmis dan Mc. Taggart (1988, p.11). Prosedur penelitian dalam penelitian tindakan kelas ini mencakup 4 tahapan : (1) perencanaan, (2) tindakan, (3) observasi, dan (4 ) refleksi.

Tempat dan Waktu Penelitian

Tempat penelitian yaitu di SD Timuran, Kecamatan Mergangsan, Kota Yogyakarta, Daerah Istimewa Yogyakarta. Waktu penelitian dilaksanakan pada tahun pelajaran 2013/2014 tepatnya pada semester 2. Penelitian dilakukan selama 2 minggu pada bulan Februari sampai Maret.

\section{Subjek Penelitian}

Subjek yang akan dikenai tindakan adalah siswa kelas V SD Timuran. Jumlah semua siswa sebanyak 25 orang dengan jumlah siswa perempuan 14 orang dan siswa laki-laki 11 orang.

\section{Instrumen pengumpulan data}

Teknik pengumpulan data yang digunakan dalam penelitian tindakan kelas ini observasi, angket, tes dan dokumentasi.

\section{Teknik Analisis Data}

Teknik analisis data yang digunakan pada penelitian ini adalah analisis deskriptif. Pendekatan deskriptif ada dua macam, yaitu kuantitatif dan kualitatif. Penelitian ini menggunakan pendekatan kuantitatif untuk menganalisis data berupa hasil tes karena datanya berupa rata-rata dan persentase hasil belajar siswa. Data kemudian disajikan dalam bentuk tabel dan grafik. Sedangkan pendekatan kualitatif digunakan untuk menganalisis data berupa hasil observasi dan angket.

\section{Hasil Penelitian Dan Pembahasan}

\section{Hasil Pra Penelitian}

Sebelum diberi tindakan peneliti melakukan observasi, berdasarkan wawancara dengan guru kelas V SDN Timuran, diperoleh hasil sebagai berikut. (1) Guru biasanya mengajarkan materi unsur dan sifat-sifat bangun ruang hanya menggunakan media pembantu hanya menggambar di papan tulis, (2) materi unsur dan sifat-sifat bangun ruang sulit untuk dipahami, sehingga sebagian siswa yang berada di kelas VI masih belum paham, meskipun di kelas tersebut ada pengulangan materi tersebut, (3) proses pembelajaran unsur dan sifat-sifat bangun ruang kelas V SDN Timuran belum mendapatkan hasil yang maksimal, dan (4) siswa kurang tertarik mengikuti pembelajaran hal ini berakibat pada suasana belajar yang kurang menyenangkan (respon siswa kurang), karena aktivitas siswa kurang dan penguasaan siswa terhadap materi unsur dan sifat-sifat bangun ruang masih abstrak. Selain wawancara dengan guru kelas $\mathrm{V}$, peneliti juga mewawancarai kepala sekolah dan guru kelas VI SDN Timuran, beliau menjelaskan bahwa sering merasa kesulitan pada materi sifat-sifat bangun ruang, keterangan ini diperoleh dari hasil ujian 
Jurnal Prima Edukasia, 4 (2), Juli 2016 - 167

Novi Kristiani, Zuhdan Kun Prasetyo

nasional. Oleh karena itu karakteristik siswa yang masih dalam taham oprasional konkret, maka dalam pembelajaran matematika peneliti tertarik untuk membuat penelitian dengan judul efektivitas pembelajaran matematikan dengan menggunakan media benda konkret pada kelas V di SDN Timuran.

Berdasarkan hasil tersebut peneliti menyusun rencana penelitian tindakan untuk memperbaiki pembelajaran matematika kususnya materi unsur dan sifat-sifat bangun ruang, termasuk diantaranya penyusunan RPP, LKS, kisi-kisi soal dan dilakukannya tes pra tindakan untuk mengetahui kemampuan awal siswa terhadap pembelajaran matematika.

Berikut disajikan persentase perolehan nilai tes pratindakan siswa kelas V SDN Timuran Yogyakarta.

Tabel 1. Hasil Sebelum diberi Tindakan

\begin{tabular}{cc}
\hline Keterangan & Nilai Pratindakan \\
\hline Nilai tertinggi & 80 \\
Nilai terendah & 45 \\
Rata-rata nilai & 65,40 \\
Persentase siswa belajar tuntas & $28 \%$
\end{tabular}

Nilai rata-rata hasil tes pratindakan diatas siswa kelas V SDN Timuran masih rendah yaitu 65,40 dan baru 7 dari 25 siswa yang mencapai KKM yang ditetapkan yaitu 75 atau sebesar $28 \%$ yang mencapai ketuntasan.

Berdasarkan Tabel 1 dapat disimpulkan bahwa penguasaan siswa pada pembelajaran matematika materi unsur dan sifat-sifat bangun ruang masih rendah dan memerlukan perbaikan. Dari hasil tes pratindakan diperoleh nilai ratarata sebesar 65,40. Jumlah siswa yang telah mencapai KKM sebanyak 7 siswa (28\%) dan sebanyak 18 siswa (72\%) belum mencapai KKM yang ditentukan dalam pembelajaran matematika. Dengan melihat hasil dari nilai pratindakan tersebut dikarenakan karena guru kurang melibatkan siswa secara langsung dalam pembelajaran matematika yang sedang diajarkan, alat peraga yang digunakan kurang menyenangkan bagi siswa sehingga siswa merasa bosan dan bermain sendiri dengan temannya. Situasi pembelajaran yang demikian tidak akan menguntungkan dan tidak efektif.

Melalui hasil diskusi dengan guru kelas, kepala sekolah dan peneliti diperoleh kesepakatan bahwa guru kelas $\mathrm{V}$ bersedia melaksanakan tindakan untuk memperbaiki pembelajaran matematika. Guru kelas sangat senang karena ada inovasi yang akan dilakukan untuk memperbaiki pembelajaran di kelasnya yang diharapkan dapat meningkatkan efektivitas pembelajaran matematika yang terlihat kenaikan nilai rata-rata pada siswa dan proses pembelajaran yang efektif diantaranya dalam pembelajaran ada aktivitas visual, (visual activities) seperti membaca, menulis, melakukan eksperimen dan demontrasi; (b) aktifvitas lisan (oral activities) seperti membaca, diskusi; (c) aktivitas mendengarkan (listening activities) seperti mendengarkan penjelasan guru, ceramah, pengarahan

\section{Hasil Pelaksanaan Penelitian Tindakan Kelas}

Pelaksanaan Tindakan Siklus I

\section{Pertemuan I}

Siklus I dilaksanakan dalam dua kali pertemuan. Pelaksanaan pertama dilaksanakan tanggal 3 Maret untuk membahas tentang sifatsifat bangun ruang dengan alokasi waktu 70 menit

\section{Perencanan}

Kegiatan perencanaan penelitian tindakan pembelajaran matematika yang dilakukan adalah menyusun RPP, LKS, kisi-kisi soal.

\section{Tindakan}

Kegiatan tindakan yang dilakukan guru adalah menyampaikan tujuan pembelajaran yang akan dicapai. Siswa mengidentifikasi dan mengelompokan benda-benda disekitas kelas yang berbentuk kubus dan balok (tempat kapur, kotak susu, kotas sabun, kotak pasta gigi).Siswa dibagi menjadi bebarapa kelompok dan duduk sesuai dengan kelompoknya. Siswa kemudian dibagikan LKS dan mengejarkan secara kelompok. Siswa mengamati berbagai model kubus dan alat peraga lain seperti kotak kabur, kotak sabun, kotak pasta gigi dan sebagainya kemudian mengidentivikasi jumlah rusuk, titik sudut dan bidang sisinya. Kemudian siswa membuat kerangka kubus dan balok dari sedotan dan plastisin. Sedotan dipotong-potong sesuai dengan ukuran yang telah ditetapkan dalam lembar kegiatan. Sedotan tersebut dianggap sebagai rusuk. Plastisin dibuat sebesar kelereng untuk dijadikan sebagai titik sudut. Setelah siswa menyelesaikan LKS dan lembar kegiatan, siswa dan guru membahas bersama-sama. Salah satu siswa dalam kelompok secara bergantian mem- 
Jurnal Prima Edukasia, 4 (2), Juli 2016 - 168

Novi Kristiani, Zuhdan Kun Prasetyo

presentasikan hasil diskusi kelompoknya, serta menunjukan hasil kerangka kubus dan balok yang telah dibuat. Observasi

Observasi yang dilakukan adalah observasi terhadap siswa dan proses pembelajaran, efektifitas pembelajaran dengan menggunakan media benda konkret dapat dilihat pada Tabel 2:

Tabel 2. Hasil Pengamatan Aktivitas Siswa Siklus I Pertemuan 1

\begin{tabular}{cccc}
\hline \multicolumn{4}{c}{ Hasil Pengamatan } \\
\hline \multicolumn{3}{c}{ Pertemuan I } \\
\hline \multicolumn{4}{c}{ Obs 1 } \\
\hline Skor & Persentase & Skor & Persentase \\
\hline 5 & $50 \%$ & 5 & $50 \%$ \\
\hline
\end{tabular}

Pada pertemuan 1 dan, dari 10 indikator yang diamati sebanyak 5 indikator yang belum mencapai harapan yaitu indikator 2 tentang sebanyak $\geq 75 \%$ siswa yang diberi pertanyaan menjawab pertanyaan dari guru belum mencapai hasil yang diharapkan, indikator 3 yaitu sebanyak $\geq 75 \%$ siswa belum dapat merespon masalah yang diberikan, indikator 7 yaitu sebanyak $\geq 75 \%$ siswa belum berdemontrasi menggunakan media konkret dengan benar, indikator 8 sebanyak $\geq 75 \%$ siswa belum berdiskusi menanggapi hasil kelompok lain, dan indikator 9 yaitu sebanyak $\geq 75 \%$ siswa belum mencatat rangkuman dan kesimpulan.

Hasil pengamatan keterlaksanaan pembelajaran berdasarkan hasil observasi, dapat dilihat pada Tabel 3:

Tabel 3. Persentase Keterlaksanaan Pembelajaran

\begin{tabular}{cccc}
\hline \multicolumn{4}{c}{ Hasil Pengamatan } \\
\hline \multicolumn{3}{c}{ Pertemuan I } \\
\hline Obs 1 & Obs 2 \\
\hline Skor & Persentase & Skor & Persentase \\
\hline 16 & $72,72 \%$ & 15 & $68,18 \%$ \\
\hline
\end{tabular}

Pada pertemuan 1, dari 22 indikator yang diamati ada 7 indikator yang belum terlaksana. Diantaranya indikator 3 tentang guru memotivasi siswa, indikator 4 tentang guru memberikan masalah yang akan dijadikan topik dalam pembelajaran geometri, indikator 10 tentang guru memotivasi siswa untuk aktif dalam kerja kelompok, indikator 12 tentang guru meminta kelompok lain untuk menanggapi hasil kerja kelompok yang presentasi, indikator 16 tentang guru memberikan reward terhadap kemajuan yang diperoleh siswa, indikator 18 yaitu guru melaksanakan pembelajaran sesuai dengan alokasi waktu yang direncanakan, dan indikator 20 yaitu tentang guru melaksanakan tindak lanjut dengan memberikan arahan atau kegiatan atau tugas sebagai bagian remidi/pengayaan sehingga skor rata-rata persentase baru mencapai $72,72 \%$.

\section{Refleksi}

Refleksi hasil rata-rata tes siklus I menunjukkan adanya peningkatan nilai rata-rata dibandingkan nilai tes pratindakan. Hal ini dibuktikan dengan perolehan nilai rata-rata pada tes pratindakan 65,40 sedangkan pada tes siklus i rata-rata 81,40. Berdasarkan hasil observasi dan refleksi pada siklus I, pembelajaran dengan menggunakan media benda konkret masih belum efektif. Untuk itu diperlukan pembelajaran ulang pada siklus selanjutnya yaitu siklus II. Berbagai kekurangan dan kelebihan pada siklus I dijadikan acuan untuk perbaikan pada siklus berikutnya.

\section{Pertemuan II}

Pertemuan II siklus I membahas tentang jaring-jaring bangun ruang dengan alokasi waktu 70 menit.

\section{Perencanaan}

Kegiatan perencanaan penelitian tindakan pembelajaran matematika yang dilakukan adalah menyusun RPP, LKS, kisi-kisi soal.

\section{Tindakan}

Kegiatan tindakan yang dilakukan guru adalah menyampaikan tujuan pembelajaran yang akan dicapai. Siswa mempratekan dengan kubus dan balok (tempat kapur, kotak susu, kotas sabun, kotak pasta gigi) menjadi jaringjaring balok da kubus. Siswa dibagi menjadi bebarapa kelompok dan duduk sesuai dengan kelompoknya. Siswa kemudian dibagikan LKS dan mengejarkan secara kelompok. Siswa mempraktekkan dengan menggunting alat peraga lain seperti kotak kabur, kotak sabun, kotak pasta gigi. Setelah siswa menyelesaikan LKS dan lembar kegiatan, siswa dan guru membahas bersama-sama. Salah satu siswa dalam kelompok secara bergantian mempresentasikan hasil diskusi kelompoknya, serta menunjukan hasil jarring-jaring kubus dan balok yang telah dibuat. 
Jurnal Prima Edukasia, 4 (2), Juli 2016 - 169

Novi Kristiani, Zuhdan Kun Prasetyo

\section{Observasi}

Observasi yang dilakukan adalah observasi terhadap siswa dan proses pembelajaran dengan menggunakan media benda konkret dapat dilihat pada tabel 4 berikut.

Tabel 4. Persentase Keterlaksanaan Pembelajaran

\begin{tabular}{cccc}
\hline \multicolumn{4}{c}{ Hasil Pengamatan } \\
\hline \multicolumn{3}{c}{ Pertemuan II } \\
\hline Obs 1 & Obs 2 \\
\hline Skor & Persentase & Skor & Persentase \\
\hline 16 & $72,72 \%$ & $\mathbf{1 6}$ & $72,72 \%$ \\
\hline
\end{tabular}

Pada pertemuan II, dari 22 indikator yang diamati ada 6 indikator yang belum terlaksana. Diantaranya indikator 3 tentang guru memotivasi siswa, indikator 4 tentang guru memberikan masalah yang akan dijadikan topik dalam pembelajaran geometri, indikator 10 tentang guru memotivasi siswa untuk aktif dalam kerja kelompok, indikator 12 tentang guru meminta kelompok lain untuk menanggapi hasil kerja kelompok yang presentasi, indikator 16 tentang guru memberikan reward terhadap kemajuan yang diperoleh siswa, indikator 18 yaitu guru melaksanakan pembelajaran sesuai dengan alokasi waktu yang direncanakan, sehingga skor rata-rata persentase baru mencapai 72,72.

Hasil observasi pengamatan aktivitas siswa dalam pembelajaran dengan menggunakan media benda konkret dapat dilihat pada Tabel 5:

Tabel 5. Hasil Pengamatan Aktivitas Siswa Siklus I Pertemuan II

\begin{tabular}{cccc}
\hline \multicolumn{4}{c}{ Hasil Pengamatan } \\
\hline \multicolumn{3}{c}{ Pertemuan II } \\
\hline \multicolumn{4}{c}{ Obs 1 } \\
\hline Skor & Persentase & Skor & Persentase \\
\hline 5 & $50 \%$ & 5 & $50 \%$ \\
\hline
\end{tabular}

Hasil rata-rata tes siklus I menunjukkan adanya peningkatan nilai rata-rata dibandingkan nilai tes pratindakan. Hal ini dibuktikan dengan perolehan nilai rata-rata pada tes pratindakan 65,40 sedangkan pada tes siklus 1 rata-rata 81,40 . Hasil perbandingan nilai tes sebelum perlakuan dan tes siklus I dapat dilihat pada Tabel 6:
Tabel 6. Nilai Tes Setelah Tindakan Siklus I

\begin{tabular}{ccc}
\hline Keterangan & Pretest & Siklus I \\
\hline Skor rata-rata & $\mathbf{6 5 , 4 0}$ & $\mathbf{8 1 , 4 0}$ \\
Skor maksimal & $\mathbf{8 0}$ & $\mathbf{1 0 0}$ \\
Skor minimal & $\mathbf{4 5}$ & $\mathbf{6 5}$ \\
Persentase Keterlaksanaan & $\mathbf{0}$ & $\mathbf{7 1 , 5 8 \%}$ \\
Pembelajaran & $28 \%$ & $68 \%$ \\
Persentase Ketuntasan &
\end{tabular}

Berdasarkan Tabel 6 terjadi peningkatan persentase siswa yang mencapai ketuntasan belajar dari 7 siswa atau $28 \%$ pada tes sebelum tindakan menjadi 17 siswa atau $68 \%$ pada tes siklus I, tetapi belum memenuhi kriteria keberhasilan penelitian pada siklus I yang ditetapkan yaitu 75\% siswa mencapai KKM yaitu 75 .

\section{Refleksi}

Sesuai hasil penelitian pada siklus I, secara umum pelaksanaan pembelajaran dengan menggunakan media benda konkret siswa kelas V SD Timuran belum berjalan belum maksimal, karena belum mencapai semua kriteria keberhasilan karena disebabkan beberapa hal. Berikut adalah beberapa permasalahan yang muncul: (1) guru memotivasi siswa tentang pentingnya memahami materi geometri dalam kehidupan sehari-hari belum terlaksana, (2) guru belum memberikan masalah yang akan dijadikan topik dalam pembelajaran geometri, (3) guru belum memotivasi siswa untuk aktif dalam kerja kelompok, (4) guru belum meminta kelompok lain untuk menanggapi hasil kerja kelompok yang presentasi, (5) guru belum memberikan reward terhadap kemajuan yang diperoleh siswa, (6) pengaturan waktu masih kurang tepat, guru masih banyak mendominasi untuk menjelaskan penggunaan media benda konkret untuk penyelesaian geometri, (7) guru belum melakukan refleksi atau merangkum dengan melibatkan siswa, sehingga pengetahuan yang diperoleh siswa kurang mantap, (8) beberapa siswa yang memiliki kemampuan rendah masih berada dalam satu kelompok atau pembagian kelompok belum merata sesuai tingkat kemampuan berfikirnya. Kerja sama dalam kelompok belum berjalan dengan maksimal kadang-kadang siswa bekerja untuk menyelesaikan soal yang menjadi bagianya sendiri tidak dipantau oleh teman yang lain dan (9) siswa yang belum mencapai KKM masih belum sesuai dengan target yang ditentukan.

Oleh karena itu, untuk mengatasi beberapa permasalahan yang muncul pada siklus I, 
Jurnal Prima Edukasia, 4 (2), Juli 2016 - 170

Novi Kristiani, Zuhdan Kun Prasetyo

direkomendasikan pada siklus II untuk diberikan perlakuan yang berbeda agar menyempurnakan tindakan. Berikut ini beberapa rekomendasi yang dilakukan meliputi (a) pemberian motivasi siswa untuk aktif dalam kerja kelompok, (b) meminta kelompok lain untuk menanggapi hasil kerja kelompok yang presentasi, (c) memberikan reward terhadap kemajuan yang diperoleh siswa dan (d) menggunakan waktu secara efektif dengan cara mentaati pembagian waktu sesuai yang telah direncanakan dalam RPP.

Berdasarkan hasil pengamatan dan evaluasi hasil diskusi dengan guru yang sekaligus sebagai kolaboratornya, ada beberapa hal yang penting yang dapat direfleksikan kedalam tindakan selanjutnya agar pelaksanan pembelajaran dapat berjalan efektif. Secara kualiatas pelaksanaan proses pembelajaran dengan media benda konkret mengalami peningkatan, akan tetapi masih belum maksimal sesuai yang diharapkan. Hal tersebut dapat dilihat dari kondisi atau keadaan pada saat pelaksanaan pembelajaran beberapa siswa masih ada yang belum melakukan diskusi dengan kelompoknya dan pada saat guru mendemontrasikan media konkret juga masih terlihat beberapa anak yang ramai.

Namun demikian masih ada catatan dan rekomendasi supaya hal tersebut dapat diperbaiki di siklus ke dua, yaitu sebagai berikut : (a) menurut hasil evaluasi masih ada 8 siswa yang belum mencapai KKM, (b) setiap siswa belum mengalami sendiri penggunaan media benda konkret dalam materi unsur dan sifat-sifat bangun ruang, (c) penggunaan bahasa tulis kurang efektif, (d) alokasi waktu perlu diperhatikan. Pada pembelajaran pertama siklus I peneliti masih menambahkan waktu 10 menit, (e) siswa aktif dalam mengikuti pembelajaran, namun masih ada beberapa siswa yang belum terfokus pada pembelajaran dan cenderung ramai, (f) pembagian kelompok perlu diatur kembali agar kemampuan kelompok merata dan (g) dalam kerja kelompok perlu diberi arahan, supaya kondisi kelas lebih kondusif.

Berdasarkan hasil observasi dan refleksi pada siklus I, pembelajaran dengan menggunakan media benda konkret masih belum efektif. Untuk itu diperlukan pembelajaran ulang pada siklus selanjutnya yaitu siklus II. Berbagai kekurangan dan kelebihan pada siklus I dijadikan acuan untuk perbaikan pada siklus berikutnya.
Pelaksanaan Tindakan Siklus II

\section{Pertemuan I}

Pertemuan I siklus II dilaksanakan tanggal 10 Maret 2014, membahas tentang unsur, sifat-sifat bangun ruang limas dan prisma.

\section{Perencanaan}

Sebelum dilaksanakannya proses pembelajaran peneliti mempersiapkan media benda konkret dalam pembelajaran, yaitu berupa kotak sabun bekas, kotak pasta gigi, kotak susu dan kotak kapur, piramid sejumlah 6 karena siswa berjumlah 25 dan siswa juga membawa alat peraga media konkret dari rumah sehingga nantinya dalam pelaksanaan siswa dikelompokan secara heterogen dalam 5 kelom-pok supaya saling bekerja sama dan harapan siswa akan aktif dan pembelajaran dapat efektif.

Tahap perencanaan selanjutnya adalah pembuatan LKS dan soal-soal evaluasi yang terlebih dahulu divalidasi oleh dosen. Selain itu peneliti juga menyiapkan instrument penelitian untuk pengumpulan data berupa pedoman observasi untuk siswa dan guru. Persiapan terakhir yang dilakukan adalah peneliti memperikan RPP yang sudah dibuat dan menjelaskan kepada guru tentang proses pembelajaran yang akan dilaksanakan agar proses pembelajaran dapat berjalan dengan baik.

\section{Tindakan}

Pada kegiatan inti, siswa diajak mengidentifikasi benda-benda di sekitar kelas yang berbentul limas dan prisma. Siswa menyebutkan almari, penghapus atap sekolah. Kemudian guru menunjukan model limas (limas tegak segitiga dan limas tegak segiempat) dan prisma (prisma tegak segitiga dan limas tegak segiempat). Siswa mengamati perbedaan model tersebut dengan sesakma. Kemudian siswa dibagi beberapa kelompok yang telah terbagi rata kemampuannya (kemampuan tinggi, sedang, dan rendah). Siswa dibagikan Lembar Kerja Siswa (LKS), lembar kegiatan, dan berbagai model lias dan prisma, yang terbuat dari kertas karton. Siswa secara berkelompok mengerjakan LKS dan Lembar Kerja. Siswa mengamati model dan gambar limas serta prisma yang ada di LKS, kemudian siswa mengidentifikasi bidang sisi, rusuk titik sudut limas dan prisma. Setelah itu siswa secara berkelompok membuat kerangka limas dan prisma. Kerangka 
Jurnal Prima Edukasia, 4 (2), Juli 2016 - 171

Novi Kristiani, Zuhdan Kun Prasetyo

prisma dan limas terbuat dari sedotan dan plastisin dengan ukuran dan sesuai dengan yang ditentukan guru. Sedotan dirangkai dan dianggap sebagai rusuk, sedangkan plastisin yang dibuat bulat-bulat seperti kelereng dianggap sebagai titik sudut. Siswa menjawab pertanyaan yang ada dalam LKS dan lembar kegiatan. Siswa mempresentasikan hasil kerjanya disertai tanggapan dari guru dan kelaompok lain.

Dalam kegiatan penutup siswa dan guru kemudian menyimpulkan materi bahwa limas segitiga mempunyai 4 bidang sisi, 4 titik sudut, dan 6 rusuk. Limas tegak segiempat mempunyai 5 bidang sisi, 5 titik sudut, dan 8 rusuk. Prisma tegak segitiga mempunyai 5 bidang sisi, 6 titik sudut, dan 9 rusuk sedangkan prisma tegak segiempat mempunyai 6 sisi, 8 titik sudut, dan 12 rusuk. Siswa juga menyimpulkan bahwa balok dan kubus merupakan prisma tegak segiempat. Guru melakukan refleksi pembelajaran dilanjutkan dengan tes akhir untuk mengetahui penyerapan materi dan terakhir memberikan pekerjaan rumah untuk mencatat benda-benda yang berbentuk limas dan prisma yang ada dirumah masing-masing.

\section{Observasi}

Berdasarkan observasi, maka hasil pengamatan aktivitas siswa, dan keterlaksanaan pembelajaran dengan menggunakan media benda konkret dapat dilihat pada Tabel 7:

Tabel 7. Hasil Pengamatan Aktivitas SiswaSiklus II Pertemuan I

\begin{tabular}{cccc}
\hline \multicolumn{4}{c}{ Hasil Pengamatan } \\
\hline \multicolumn{4}{c}{ Pertemuan I Siklus II } \\
\hline \multicolumn{3}{c}{ Obs 1 } & Obs 2 \\
\hline Skor & Persentase & Skor & Persentase \\
\hline 9 & $90 \%$ & 9 & $90 \%$ \\
\hline
\end{tabular}

Pada pertemuan I siklus, dari 10 indikator yang diamati sebanyak 1 indikator yang belum mencapai harapan yaitu indikator 9 yaitu sebanyak $\geq 75 \%$ siswa belum mencatat rangkuman dan kesimpulan. Berdasarkan hasil observasi terhadap ke-terlaksanaan pembelajaran dengan mengguna-kan media benda konkret dapat dilihat pada Tabel 8:

Tabel 8. Persentase Keterlaksanaan Pembelajaran Siklus II Pertemuan I

\begin{tabular}{c}
\hline \multicolumn{2}{c}{ Hasil Pengamatan } \\
\hline Siklus II Pertemuan I \\
\hline Obs 1 Obs 2
\end{tabular}

\begin{tabular}{cccc}
\hline Skor & Persentase & Skor & Persentase \\
\hline 22 & $100 \%$ & 22 & $100 \%$ \\
\hline Pada & pertemuan & 2 2, dari 22 indikator
\end{tabular}
sudah terlaksana semua.

Refleksi

Hasil refleksi pelaksanaan pembelajaran sangat dipengaruhi oleh kemampuan dan ketepatan guru dalam memilih dan menggunakan media pembelajaran.

\section{Pertemuan II}

Pertemuan II siklus II dilaksanakan pada tangga 12 Meret 2014, membahas tentang jaring-jaring limas dan prisma

\section{Perencanaan}

Kegiatan perencanaan penelitian tindakan pembelajaran matematika yang dilakukan adalah menyusun RPP, LKS, dan soal.

\section{Pelaksanaan}

Pelaksaaan kegiatan yang dilakukan guru adalah memberikan apersepsi dengan mengkaitkan materi dengan konteks yang ada di sekitas siswa. Guru mengulang pelajaran yang telah lalu yaitu sifat-sifat prisma (prisma tegak segitiga, prisma tega segiempat) dan limas (limas tegak segitiga, limas tegak segiempat). Sebagian besar siswa telah menyebutkan jumlah bidang sisi, titik sudut dan ruruk dengan tepat. Guru memberitahukan bahwa pelajaran pada pertemuan ini membahas tentang jaring-jaring limas dan prisma. Guru menjelaskan pentingnya pengetahuan tentang jaring-jaring yang akan dipelajari, misalnya ketika akan membuat kotak snack, atap rumah dan kotak pensil kardus, rumah/bangunan yang berbentuk piramida.

Pelaksanaan kegiatan inti siswa dibagi menjadi beberapa kelompok. Setiap kelompok terdiri 5 orang yang berkemampuan berbedabeda. Siswa diberikan LKS dan model limas (limas tegak segitiga dan limas tegak segiempat) disamping model limas dan prisma yang dibawa siswa dari rumah seperti kotak sabun, kotak pasta gigi, kotak susus. Siswa mengerjakan LKS secara berkelompok. Siswa mengiris/ menggunting model tersebut tepat pada rusuknya. Siswa merebahkan irisan model berbentuk rangkaian bangun datar. Siswa menggambar jaring-jaring limas dan prisma dalam LKS. Siswa menjawab pertanyaan pada LKS dan dilanjutkan salah satu kelompok mempresen- 
Jurnal Prima Edukasia, 4 (2), Juli 2016 - 172

Novi Kristiani, Zuhdan Kun Prasetyo

tasikan hasil kerja kelompok secara bergantian disertai tanggapan dari guru dan siswa lainnya. Jaring-jaring yang berhasil ditemukan siswa ditempel dan digambar dipapan tulis agar kelompok lain mengetahui. Hal ini dikarenakan jaring-jaring yang ditemukan tiap kelompok berbeda-beda.

Pada kegiatan akhir siswa dan guru menyimpulkan materi bersama-sama yakni bahwa setiap bangun pasti mempunyai jaring-jaring yang berbeda-beda.

\section{Observasi}

Berdasarkan observasi maka hasil pengamatan aktivitas siswa pada pembelajaran dengan menggunakan media benda konkret dapat dilihat pada Tabel 9:

Tabel 9. Hasil Pengamatan Aktivitas Siswa Siklus II Pertemuan II

\begin{tabular}{cccc}
\hline \multicolumn{4}{c}{ Hasil Pengamatan } \\
\hline \multicolumn{4}{c}{ Siklus II Pertemuan II } \\
\hline & Obs 1 & \multicolumn{3}{c}{ Obs 2 } \\
\hline Skor & Persentase & Skor & Persentase \\
\hline 9 & $90 \%$ & 9 & $90 \%$ \\
\hline
\end{tabular}

Pada pertemuan II siklus II, dari 10 indikator yang diamati sebanyak 1 indikator yang belum mencapai harapan yaitu indikator 9 yaitu sebanyak $\geq 75 \%$ siswa belum mencatat rangkuman.

Hasil observasi keterlaksanaan pembelajaran dengan menggunakan media benda konkret dapat dilihat pada Tabel 10.

Tabel 10. Persentase Keterlaksanaan

Pembelajaran Siklus II Pertemuan II

\begin{tabular}{cccc}
\hline \multicolumn{3}{c}{ Hasil Pengamatan } \\
\hline \multicolumn{3}{c}{ Pertemuan II Siklus II } \\
\hline Obs 1 & \multicolumn{3}{c}{ Obs 2 } \\
\hline Skor & Persentase & Skor & Persentase \\
\hline 22 & $100 \%$ & 22 & $100 \%$ \\
\hline
\end{tabular}

Pada pertemuan II siklus II, dari 22 indikator yang diamati semua indikator sudah terlaksana. Hasil observasi kegiatan guru dalam pembelajaran yang menggunakan media benda konkret sudah lebih dari $75 \%$ sehingga dikatakan guru telah mencapai keterlaksanaa pembelajaran yang efektif dengan menggunakan media benda konkret.

Hasil Tes

Hasil tes siklus II siswa pada penelitian tindakan kelas yang dilakukan dalam siklus II menunjukkan peningkatan hasil pada nilai ratarata kelas yaitu dari 81,40 pada siklus I menjadi 88,32 pada siklus II. Persentase siswa yang mencapai KKM 75 juga meningkat dari $68 \%$ pada siklus I menjadi $88 \%$ pada siklus II. Perbandingan nilai siswa siklus I dan dapat dilihat pada Tabel 11.

Tabel 11. Perbandingan Perolehan Nilai Siswa Siklus I dan II

\begin{tabular}{|c|c|c|c|}
\hline \multirow{2}{*}{ No } & \multirow{2}{*}{ Keterangan } & \multicolumn{2}{|c|}{ Nilai } \\
\hline & & Siklus I & Siklus II \\
\hline 1 & Nilai tertinggi & 100 & 100 \\
\hline 2 & Nilai terendah & 65 & 68 \\
\hline 3 & Rata-rata nilai & 81,40 & 88,32 \\
\hline 4 & $\begin{array}{l}\text { Persentase } \\
\text { belajar tuntas }\end{array}$ & $68 \%$ & $88 \%$ \\
\hline
\end{tabular}

Refleksi

Hasil refleksi pelaksanaan pembelajaran sangat dipengaruhi oleh kemampuan dan ketepatan guru dalam memilih dan menggunakan media pembelajaran Hasil angket respons siswa menunjukan bahwa keefektifan pembelajaran matematika dengan menggunakan media benda konkret memberikan respon yang sangat baik, serta pencapaian nilai tes telah menunjukan hasil sesuai dengan KKM. Hal tersebut menunjukkan bahwak kriteria pada penelitian ini telah tercapai sehingga bisa dikatakan penelitian ini berhasil. Dengan tercapainya kriteria keberhasilan pada penelitian siklus II ini maka peneliti memutuskan untuk menghentikan penelitian tindakan tersebut.

\section{Pembahasan}

Hasil tes siklus I dan II siswa pada penelitian tindakan kelas yang telah dilakukan dalam 2 siklus menunjukkan peningkatan hasil pada nilai rata-rata kelas yaitu dari 81,40 pada siklus I menjadi 88,32 pada siklus II. Persentase siswa yang mencapai KKM 75 juga meningkat dari $68 \%$ pada siklus I menjadi $88 \%$ pada siklus II.

Begitu juga hasil angket respon siswa mengalami peningkatan seperti yang terlihat dari siklus I yang memberikan respon sangat baik mencapai $98 \%$ meningkat menjadi $100 \%$ pada siklus II. Hal tersebut menunjukkan bahwa kriteria pada penelitian ini telah tercapai sehingga bisa dikatakan penelitian tersebut berhasil. Dengan tercapainya kriteria keberhasilan pada penelitian siklus II ini maka peneliti memutus- 
Jurnal Prima Edukasia, 4 (2), Juli 2016 - 173

Novi Kristiani, Zuhdan Kun Prasetyo

kan untuk menghentikan penelitian tindakan tersebut.

Pelaksanaan kefektifitas pembelajaran sangat dipengaruhi oleh kemampuan dan ketepatan guru dalam memilih dan menggunakan media pembelajaran. Penelitian ini merupakan penelitian tindakan kelas dengan melaksanakan efektifitas pembelajaran dengan menggunakan media benda konkret. Penelitian ini dilaksanakan dalam 2 siklus. Siklus pertama terdiri atas 2 pertemuan, siklus kedua 2 kali pertemuan. Sebelum kegiatan pembelajaran dilakukan, guru mempersiapkan perangkat pembelajaran antara lain RPP, alat peraga media benda konkret, soal evaluasi, LKS, lembar pengamatan siswa dan guru.

Dalam pelaksanaan tindakan kelas, guru perperan sebagai pelaksana dan membimbing siswa. Sedangkan peneliti bertindak sebagai pengamat jalannya pembelajaran. Semua aktivitas guru dan siswa dalam kelas diamati dan dinilai dengan berpedoman pada lembar pengamatan siswa dan guru. Pada setiap akhir proses pembelajaran, hasil pengamatan didiskusikan dengan guru dan kepala sekolah. Dilihat dari pengamatan sejak kegiatan pertama hingga kegiatan terakhir pelaksanaan pembelajaran matematika. Hal ini dapat diketahui pada siklus I proses pembelajaran pada dasarnya sudah berjalan dengan cukup baik akan tetapi masih ada kekurangan yaitu kurangnya motivasi terhadap murid, guru juga belum melaksanakan sesuai waktu yang telah direncanakan, dan siswa kurang aktif dalam kerja kelompok

Peneliti dan guru mempunyai cara untuk mengefektivitaskan pembelajaran matematika yaitu mengotimalkan kegiatan dengan pemberian motivasi terhadap murid, dan melaksanakan pembelajaran sesuai dengan RPP. Pada siklus II kegiatan pembelajaran berjalan dengan efektif dan baik. Hal ini terjadi karena pada siklus II merupakan perbaikan dari siklus I, sehingga pada siklus II proses pembelajara dapat efektif

Proses pembelajaran yang melibatkan siswa secara aktif akan memperoleh hasil belajar yang maksimal. Peningkatan proses dan hasil belajar merupakan usaha guru dengan cara mengoptimalkan pengelolaan pembelajaran di kelas sehingga tercipta pembelajaran yang efektif dan efisien. Hasil penelitian seperti yang diduga dapat menjawab semua pertanyaan penelitian, sehingga bisa memenuhi semua kriteria keberhasilan dalam penelitian. Berdasarkan deskripsi pelaksanaan tindakan siklus I dan siklus II, yang telah menerapkan pelaksanaan pembelajaran dengan menggunakan media benda konkret seperti yang dikemukakan oleh Gagne. Menyatakan bahwa pembelajaran merupakan interaksi antara pengajar, siswa dan bahan ajar atau materi pelajaran, dengan kondisi dan situasi yang telah diatur untuk mencapai tujuan yang ditandai dengan adanya perubahan tingkah laku dan pola pikir peserta didik, pembelajaran bertahan lama seiring dengan waktu, serta pembelajaran terjadi melalui pengalaman. Hal tersebut dapat ditunjukan dalam berbagai bentuk seperti perubahan pengetahuan, pemahaman kemampuan mengingat atau memahami konsep matematika bertahan lama, serta siswa mempunyai pengalaman langsung dengan menggunakan media konkret. Namun jika dilihat dari masing-masing kriteria keberhasilan masih ada beberapa masalah yang muncul dalam pembelajaran dan akan dibahas diantaranya:

\section{Meningkatnya Nilai Rata-Rata Kelas Siswa Kelas V}

Secara umum nilai rata-rata kelas mengalami peningkatan, memanfaatkan alat peraga visual dapat meningkatkan hasil belajar dan motivasi dalam pembelajaran matematika.

Proses pembelajaran yang mengalami peningkatan kualitas, akan berpengaruh pada peningkatan nilai akhir siswa. Siswa mengikuti pembelajaran dengan lebih baik secara bertahap. Peningkatan nilai rata-rata kelas pada penelitian ini dapat dilihat pada Gambar 1.

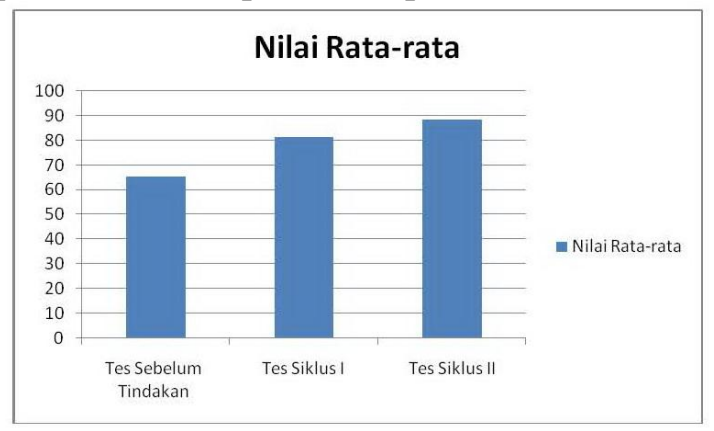

Gambar 1. Peningkatan Nilai Rata-rata

Dari Gambar 1 terlihat adanya peningkatan nilai rata-rata pada tes sebelum tindakan baru mencapai 65.40, pada tes siklus I meningkat menjadi 81.40 dan pada tes siklus II meningkat menjadi 88.32 
Jurnal Prima Edukasia, 4 (2), Juli 2016 - 174

Novi Kristiani, Zuhdan Kun Prasetyo

Dengan media benda konkret siswa bersimulasi pengalaman nyata dan dapat mendapatkan pemahaman mencapai daya ingat lebih dari 70\% seperti kerucut pengalaman Dale Edgar. Untuk memastikan efektifitas pembelajaran menurut Slavin perlu menggunakan contoh, peragaan, gambar dan diagram untuk menjadikan gagasan gamblang bagi siswa.

Sayang pada siklus I pembagian kelompok masih terlalu belum merata kemampuannya, dan jumlah media benda konkret tiap kelompok masih kurang sehingga kesempatan anak untuk mencoba media masih terbatas dan anak masih terkonsentrasi dengan soal yang menjadi bagiannya sehingga belum bisa belajar secara maksimal. Hal ini berakibat pada perolehan pengetahuan pada siklus I belum maksimal.

Berdasarkan pengamatan pada siklus I kerjasama dalam kelompok belum berjalan dengan optimal, sehingga tutor sebaya belum berjalan. Siswa masih terpaku dengan mengerjakan soal yang menjadi bagiannya. Besar kemungkinan hal itulah yang menyebabkan siswa masih melakukan kesalahan-kesalahan tersebut.

Pada siklus II kerjasama dalam kelompok ditingkatkan siswa yang berkemampuan rendah disebar dan siswa yang berkemampuan tinggi dianjurkan untuk membimbing siswa yang berkemampuan rendah, serta anak-anak diberi kesempatan untuk membawa media benda konkret dari rumah sehingga memberi kesempatan yang lebih bagi siswa untuk mencoba menggunakan media yang ada untuk menyelesaikan soal.

Meningkatnya Persentase Siswa yang Mencapai KKM

Persentase siswa yang mencapai kriteria ketruntasan minimal dari siklus I dan siklus II mengalami peningkatan. Secara umum persentase siswa yang mencapai KKM meningkat, namun masih ada beberapa siswa yang melakukan kesalahan tes.

Respon siswa terhadap keefektifan

Pembelajaran dengan media benda konkret

Respon siswa pada pembelajaran dengan menggunakan media benda konkret dari siklus I dan II dalam kategori baik dan sangat baik, hasil penelitian menyatakan bahwa terdapat pengaruh media yang signifikan terhadap motivasi belajar. Ternyata dengan media benda konkret yang digunakan di kelas $\mathrm{V}$, juga mendapatkan respon yang sangat baik dari siswa di kelas V.

Keterlaksanaan Keefektifan Pembelajaran dengan Menggunakan Media Benda Konkret

Keefektifan pembelajaran matematika dengan media benda konkret di kelas V SD dengan alokasi waktu 8 jam pelajaran. Terbagi dalam 4 pertemuan. Pada penelitian ini terbagi dalam 2 siklus, tiap siklus terdiri atas 2 pertemuan. Dari hasil observasi siklus I, pertemuan 1 persentase keterlaksanaan pembelajaran yang direncanakan baru mencapai $68,18,72 \%$ pertemuan 2 mencapai 72,72\%. Keefektifan pembelajaran matematika dengan media benda konkret menurut kriteria keberhasilan yang telah ditetapkan dikatakan belum berhasil, karena hasil yang didapatkan belum mencapai $\geq 75 \%$. Hal ini dikarenakan ada beberapa indikator yang belum terlaksana.

Catatan yang perlu diperhatikan dari PBM dari siklus I, hendaknya peneliti dengan kolabor mendiskusikan dengan matang langkah-langkah pembelajaran yang akan dilakukan agar kolaborator selaku pelaksana utama dalam KBM bisa lebih percaya diri. Tumbuhkan pula keyakinan pada kolabor bahwa model yang dicobakan dalam penelitian benar-benar mempunyai keunggulan sehingga layak untuk digunakan.

Pada siklus II, pembelajaran berjalan lebih baik hal ini dikarenakan sebelum memulai siklus II, peneliti dan kolaborator telah melakukan refleksi dan sepakat untuk memperbaiki proses pembelajaran pada siklus II. Hal ini berdampak cukup baik dilihat dari keterlaksanaan PBM. Dari 22 indikator yang diamati 100\% bisa terlaksana, sehingga hasil belajar siswa juga mengalami peningkatan.

Dari segi aktivitas siswa pada siklus I, pada pertemuan 1 dan 2 persentase ketercapain pelaksanaan pembelajaran mencapai $50 \%$, indikator 2,3,7,8,9 tentang siswa yang diberi pertanyaan belum menjawab dan siswa belum merespon masalah yang diberikan, siswa belum berdemontrasi menggunakan media konkret dengan bena, serta dalam berdiskusi siswa belum menanggapi hasik kerja kelompok lain, serta siswa belum mencatat rangkuman dan kesimpulan pembelajaran. 
Jurnal Prima Edukasia, 4 (2), Juli 2016 - 175

Novi Kristiani, Zuhdan Kun Prasetyo

Pada siklus II, pada pertemuan 1 dan 2 persentase ketercapain mencapai $90 \%$ dari 10 indikator yang diamati hanya 1 idikator yang tidak muncul yaitu kurang dari $75 \%$ siswa siswa tidak merangkum dan menyimpulkan pembelajaran, namun tidak berakibat buruk pada hasil.

\section{Simpulan dan Saran}

Simpulan

Pembelajaran matematika dengan media benda konkret dapat mmeningkatkan efektivitas pembelajaran pada siswa kelas V di SD Timuran terbukti dengan adanya aktivitas visual, aktivitas lisan, aktivitas mendengar, aktivitas menulis yang dilakukan oleh siswa dan meningkatnya nilai rata-rata ulangan harian siswa dari tessebelum tindakan rata-rata 65.40 , siklus I meningkat menjadi 81,40 dan pada siklus II meningkat menjadi 88,32 .

Pembelajaran matematika dengan media benda konkret pada siswa kelas V SD Timuran, dapat meningkatkan persentase ketuntasan siswa terhadap KKM yang ditetapkan oleh guru kelas. Pada tes sebelum tindakan siswa yang mencapai KKM 28\%, pada siklus I meningkat menjadi $68 \%$, dan pada siklus II meningkat $88 \%$.

Pembelajaran matematika dengan media benda konkret pada siswa kelas V SD Timuran mendapatkan respon yang baik dari siswa. Pada siklus I siswa yang memberikan respon baik 5 siswa dan 25 siswa memberikan respon dalam sangat baik sedangkan pada siklus II, 25 siswa memberikan respon sangat baik atau sebesar $100 \%$ siwa memberikan respon dalam kategori sangat baik sehingga melampaui target kriteria keberhasilan yang ditetapkan.

Saran

Saran yang dapat dikemukakan pada penelitian ini adalah sebagai berikut (1) bagi guru kelas $\mathrm{V}$, yang ingin meningkatkan keefektifan pembelajaran matematika dapat menggunakan media benda konkret yang telah terbukti dapat meningkatkan pada siswa kelas V SD
Timuran dan (2) bagi para peneliti lanjutan, pengggunaan media benda konkret hendaknya siswa dapat mendemontrasikan sendiri-sendiri supaya mempunyai pengalaman sendiri mendapatkan hasil yang memuaskan.

\section{Daftar Pustaka}

Depdiknas. (2003). UU no 20 tahun 2003, tentang Sistem Pendidikan Nasional.

DePorter, B. \& Hernacki, M. (2011). Quantum learning membiasakan belajar nyaman dan menyenangkan (Terjemahan Alwiyah Abdurrahman). New York: Dell Publishing. (Buku asli diterbitkan tahun 1992)

Gagne, R.M. \& Briggs, L.J. (1979). Principle of intructional design. New York: Holt, Rinehart and Winston.

Hamalik, O. (2009). Perencanaan pengajaran berdasarkan pendekatan sistem. Jakarta: Bumi Aksara

Heinich, R., Molanda, M., Russell, J.D., \& Smaldino, S.E. (1996). Intructional media and technologi for learning $\left(5^{\text {th }}\right.$ ed.). Englewood cliffs. Hoboken: A Simon \& Schuster Company.

Johnson, E.B. (2002). Contextual teaching and learning. Tousand Oaks. California: Corwin Press

Kemmis, S. \& Taggart R. (1988). The action research planner. Deakin University

Muhsetyo, G., dkk. (2007). Pembelajaran matematika SD. Jakarta: Universitas Terbuka.

Santrock, J. W. (2012). Life-span development perkembangan masa-hidup. (Terjemahan Benedictine Widyasinta) McGraw-Hill Companies Jakarta: PT Gelora Angkasa Pratama. (Buku asli diterbitkan tahun 2011).

Winkel, W.S. (2009). Psikologi pengajaran. Yogyakarta: Media Abadi. 